\title{
FIRST RECORDS OF THE CADDISFLY FAUNA (INSECTA: TRICHOPTERA) FROM THE KARADAK MOUNTAINS, WESTERN BALKANS
}

\author{
Astrit Bilalli ${ }^{1}$, Halil Ibrahimi $^{2 *}$ \& Milaim Musliu ${ }^{3}$ \\ ${ }^{1}$ Faculty of Agribusiness, University of Peja "Haxhi Zeka", “UÇK” street, 30000 Pejë, \\ Republic of Kosovo \\ ${ }^{2}$ Department of Biology, Faculty of Mathematics and Natural Sciences, University of Prishtina \\ "Hasan Prishtina", "Mother Theresa" p.n., 10000 Prishtinë, Republic of Kosovo \\ ${ }^{3}$ Institute for Environment and Health, Faculty of Contemporary Sciences and Technologies, South \\ East European University, Ilindenska 335, 1200 Tetovo, Macedonia
}

Bilalli, A., Ibrahimi, H. \& Musliu, M.: First records of the caddisfly fauna (Insecta: Trichoptera) from the Karadak Mountains, Western Balkans. Nat. Croat., Vol. 27, No. 1, 143-151, Zagreb, 2018.

The caddisfly fauna of the Karadak Mountains in the border area between Kosovo and Macedonia was previously completely unknown. We collected adult caddisfly specimens occasionally, from September 2016 to June 2017, in sixteen localities in this area. During this investigation we found 18 species belonging to the following families: Limnephilidae, Rhyacophilidae, Philopotamidae, Uenoidae and Leptoceridae. The autumnal Limnephilid species Chaetopteryx gonospina was found in one locality only, in Dëbëlldeh village in southern Kosovo, representing the first record for Kosovo. Rhyacophila fischeri, Rhyacophilidae, was found in Tanushë village in northeastern Macedonia, the first record from Macedonia. This paper is a contribution to knowledge of the distribution of Trichoptera from Kosovo and Macedonia.

Keywords: Trichoptera, Kosovo, Macedonia, Chaetopteryx gonospina, Rhyacophila fischeri

Bilalli, A., Ibrahimi, H. \& Musliu, M.: Prvi nalazi faune tulara (Insecta: Trichoptera) s planina Karadak, zapadni Balkan. Nat. Croat., Vol. 27, No. 1, 143-151, Zagreb, 2018.

Fauna tulara planina Karadak s graničnog područja između Kosova i Makedonije bila je prethodno potpuno nepoznata. Nasumično smo prikupljali odrasle jedinke od rujna 2016. do lipnja 2017. na 16 lokaliteta na tom području. Tijekom ovog istraživanja pronašli smo 18 vrsta iz sljedećih porodica: Limnephilidae, Rhyacophilidae, Philopotamidae, Uenoidae i Leptoceridae. Jesenska vrsta iz porodice Limnephilidae, Chaetopteryx gonospina pronađena je samo na jednom lokalitetu, u selu Dëbëlldeh u južnom Kosovu, i to je njen prvi nalaz za Kosovo. Rhyacophila fischeri, porodica Rhyacophilidae, pronađena je u selu Tanushë u sjeveroistočnoj Makedoniji i to je njen prvi nalaz za Makedoniju. Ovaj rad je doprinos poznavanju rasprostranjenosti tulara na Kosovu i Makedoniji.

Ključne riječi: Trichoptera, Kosovo, Makedonija, Chaetopteryx gonospina, Rhyacophila fischeri

\section{INTRODUCTION}

According to current knowledge there are more than 15000 species of the aquatic insect order Trichoptera worldwide (Morse, 2017). In Europe, more than 1100 species have

\footnotetext{
*Corresponding author: halil.ibrahimi@uni-pr.edu
} 
been recorded (e.g. Malicky, 2004; OláH, 2010; Wiberg-Larsen, 2008). Within Europe, the Balkan Peninsula is one of the most important biodiversity hotspots for caddisflies with a high rate of endemism due to the geological, hydrological and climatic features of the area (e.g. Previšić et al., 2013; SCHMidt-KLoiber et al., 2017). However data for many areas in the Balkans are still lacking. During the past decade, this order of aquatic insects has taken more attention in studies related to taxonomy, ecology and biogeography (e.g. Graf et al., 2008; Iвrahimi et al., 2012A, b, 2013, 2014a, b; KučInić et al., 2013; Malicky, 2005; OlÁH, 2010; OlÁH et al., 2011; OlÁH et al., 2013a, b, c; Previšıć et al., 2014; VučKović et al., 2011; WARINGER et al., 2009; Žıvić et al., 2006). Several areas in Kosovo have been intensively investigated during the past years for Trichoptera (GASHi et al., 2015; IвRAHIмi et al., 2012a, b, 2013, 2014a, b; OlÁH et al., 2010, 2013a, b) while in Macedonia this order of aquatic insects was investigated only sporadically (OLÁH, 2010, 2011; OlÁH \& Kovács, 2013, 2014; RimCHESKA et al., 2015; SLAVEVSKA-STAMENKOvić et al., 2016). Several new species were described recently, from both countries, such as Annitella jabllanicensis Oláh, 2014, Chaetopteroides kosovarorum Ibrahimi \& Oláh, 2013, Drusus dardanicus Ibrahimi, Vitecek \& Kučinić, 2015, Drusus krpachi Kučinić, Graf \& Vitecek, 2015, Drusus sharrensis Ibrahimi, Previšić \& Vitecek, 2015, Potamophylax alsos Oláh, 2014, Potamophylax fules Oláh \& Ibrahimi 2013, Potamophylax lemezes Oláh \& Graf, 2013, Rhyacophila liutica Oláh, 2010, (IвRAнiмi et al., 2015a, 2016; OLÁH et al., 2013a, 2013b; OláH \& KovÁcs, 2014; OlÁH, 2010; VíteceK et al., 2015).

The goal of this paper is to contribute to the faunistic list of caddisflies of Kosovo and Macedonia and in particular to provide the first insights into the caddisfly fauna of the Karadak Mountains, which have hitherto provided no records of caddisflies.

\section{MATERIAL AND METHODS}

\section{Data sampling and processing}

Adult caddisfly specimens were collected with entomological nets, handpicking and ultraviolet light traps. Ultraviolet light was placed above a white pan of $60 \mathrm{~cm}$ in diameter, filled with water and a few drops of detergent. The sampling was carried out occasionally between September 2016 and June 2017. Collected samples were preserved in $80 \%$ ethanol. The specimens were identified under a stereomicroscope with determination keys from MaLicky (2004) and Kumanski $(1985,1988)$.

Female specimens of the genus Hydropsyche Pictet, 1834 were identified only up to generic level due to the difficulties in identifying the species accurately. During our investigation we found a single male specimen of the genus Chaetopteroides Kumanski, 1987 most probably belonging to Chaetopteroides kosovarorum described recently from Kosovo (OlÁt et al., 2013b). However more specimens are needed in order to compare it with species of this genus. A single male specimen belonging to the genus Micropterna Stein, 1873 was found during this investigation at Station S1, which is a tributary of Morava River in Binçë village in Kosovo, and it was identified only up to the generic level. The aedeagus and parameres of this specimen are slightly damaged while all other characteristics are mostly similar to those of Micropterna testacea (Gmelin, 1789), and clearly different from those of Micropterna nycterobia McLachlan, 1875. More specimens from this locality are needed in order to identify its taxonomic status precisely.

The collection is deposited at the Laboratory of Zoology of the Faculty of Natural and Mathematics Sciences, University of Prishtina, Republic of Kosovo. Systematic presentation was done according to Morse (2017). 


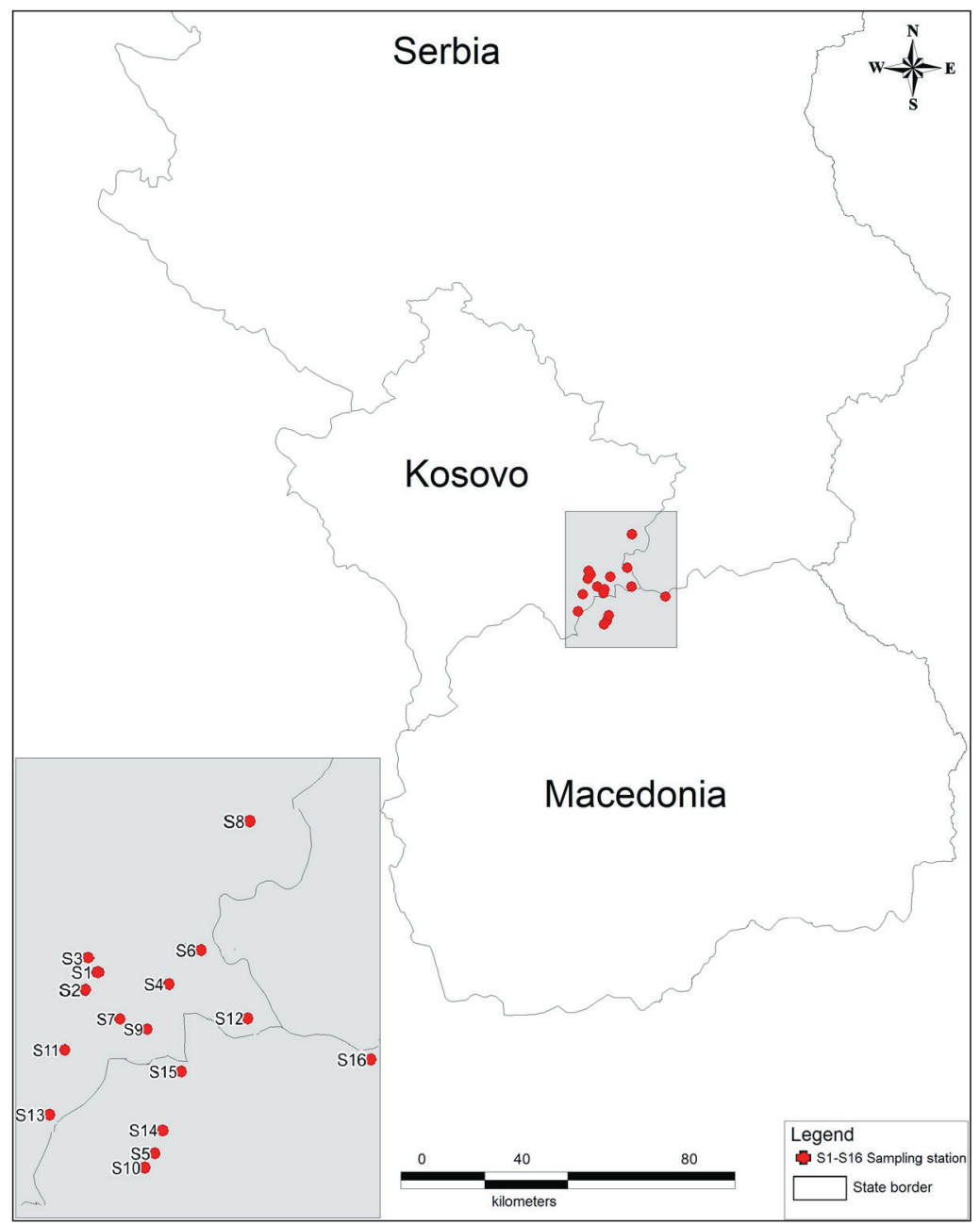

Fig. 1. Map of the sampling stations in the Karadak Mountains. Detailed data are presented in Tab. 1.

\section{Study area}

Sampling was carried out in 16 localities in the Karadak Mts. (Fig. 1 and Tab. 1). This mountainous area is shared between Kosovo and Macedonia and it is known for numerous watercourses, springs, rivulets and rivers. Freshwater ecosystems of this area belong to the Black Sea Basin and the Aegean Sea Basin. Eleven of the sampling stations are located in Kosovo in the municipalities of Gjilan, Viti, Kaçanik and Hani i Elezit and five in Macedonia in the municipalities of Čučer-Sandevo and Kumanovë (Tab. 1).

The highest peaks in the Karadak Mts. are Maja e Kopilaqës (1.490m), Maja e Zezë $(1.219 \mathrm{~m})$ and Maja Topan $(1.178 \mathrm{~m})$. The area of the Karadak Mts. is bordered by the Sharr Mts. in the north while in the south they border with the Jakupica Mts. 
Tab. 1. Locality data for the 16 sampling stations of caddisflies at the Karadak Mountains in Kosovo and Macedonia.

\begin{tabular}{|c|l|c|c|c|}
\hline Code & Sampling Stations & $\begin{array}{c}\text { Latitude } \\
{ }^{\circ} \mathrm{N}\end{array}$ & $\begin{array}{c}\text { Longitude } \\
{ }^{\circ} \mathrm{E}\end{array}$ & $\begin{array}{c}\text { Altitude } \\
\mathrm{m}\end{array}$ \\
\hline S1 & Tributary of Morava River in Binçë village, Kosovo & 42.29476 & 21.37150 & 570 \\
\hline S2 & Tributary of Morava River in Shushtë village, Kosovo & 42.28113 & 21.35911 & 573 \\
\hline S3 & Morava River in Viti town, Kosovo & 42.30628 & 21.36202 & 520 \\
\hline S4 & Tributary of Morava River in Letnicë village, Kosovo & 42.28727 & 21.45736 & 625 \\
\hline S5 & Tributary of Vardar River in Brodec Village, Macedonia & 42.14192 & 21.4403 & 912 \\
\hline S6 & Tributary of Zhegër stream in Zhegër village, Kosovo & 42.31572 & 21.53148 & 640 \\
\hline S7 & River in Dëbëlldeh village, Kosovo & 42.25454 & 21.40008 & 982 \\
\hline S8 & Llapushnicë River in Pogragjë village, Kosovo & 42.42533 & 21.55426 & 483 \\
\hline S9 & Lugu i Kopilaqës streamlet in Dëbëlldeh village, Kosovo & 42.24605 & 21.43110 & 1160 \\
\hline S10 & Streamlet before Brodec village, Macedonia & 42.130803 & 21.429318 & 652 \\
\hline S11 & Morava River in Korbliq village, Kosovo & 42.229795 & 21.336078 & 730 \\
\hline S12 & Zhegër stream in Stanqiq village, Kosovo & 42.25506 & 21.55029 & 836 \\
\hline S13 & Stream in Dërmjak village, Kosovo & 42.17264 & 21.31582 & 625 \\
\hline S14 & Stream above Brodec village, Macedonia & 42.160165 & 21.448974 & 1350 \\
\hline S15 & Streamlet before Tanushë village, Macedonia & 42.23356 & 21.42733 & 1358 \\
\hline S16 & Stream in Tabanovc village, Macedonia & 42.219713 & 21.697831 & 380 \\
\hline
\end{tabular}

\section{RESULTS}

During this investigation we found 18 species belonging to 5 families and 13 genera of Trichoptera. The distribution of species within families is as follows: Limnephilidae (10), Rhyacophilidae (4), Philopotamidae (2), Uenoidae (1) and Leptoceridae (1).

The highest number of specimens comes from three species of the Rhyacophilidae family: Rhyacophila fasciata Hagen, 1859 (39 specimens), R. fischeri Botosaneanu 1957 (14 specimens) and R. obliterata McLachlan, 1863 (12 specimens) while all other species were collected with fewer than ten specimens. The following five species were found with one specimen only each during the whole investigation period: Chaetopteryx bosniaca Marinkovic-Gospodnetic, 1959, Chaetopteryx gonospina Marinkovic-Gospodnetic, 1966, Drusus botosaneanui Kumanski, 1968, Micropterna sp., Mystacides azurea (Linnaeus, 1761) and Stenophylax meridiorientalis Malicky, 1982. Three species (Halesus digitatus (Schrank, 1781), Rhyacophila fasciata and R. obliterata) were the most widespread and were collected at five localities each, while the rest of the species were found in fewer localities. Nine species were recorded in only one locality each (Chaetopteryx bosniaca, Chaetopteryx gonospina, Drusus botosaneanui, Micropterna sp., Mystacides azurea, Potamophylax pallidus (Klapalek, 1899), Rhyacophila nubila Zetterstedt, 1840, Stenophylax meridiorientalis and Thremma anomalum McLachlan, 1876).

Systematic list of caddisflies collected at sixteen stations in the Karadak Mountains (Kosovo and Macedonia) during the period September 2016 - June 2017. Details about sampling stations are given in Tab. 1. 


\section{Family Rhyacophilidae}

\section{Rhyacophila fischeri Botosaneanu 1957}

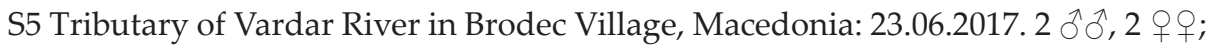
S14 Stream above Brodec village, Macedonia: 23.06.2017. 1 $\uparrow$; S15 Streamlet before

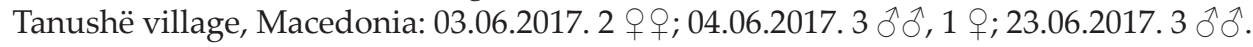
Rhyacophila obliterata McLachlan, 1863

S1 Tributary of Morava River in Binçë village, Kosovo: 27.11.2016. 1 ઈ. S9 Lugu i Kopilaqës streamlet in Dëbëlldeh village, Kosovo: 27.11.2016. 2 ふぇ. S4 Tributary of Morava River in Letnicë village, Kosovo: 04.11.2016. 3 $\widehat{\jmath}$. S11 Morava River in Korbliq village, Kosovo: 30.10.2016. $3 \hat{\jmath} \widehat{\jmath}$. S14 Stream in Dërmjak village, Kosovo: 02.10.2016. 1 ○े 2 우.

Rhyacophila fasciata Hagen, 1859

S2 Tributary of Morava River in Shushtë village, Kosovo: 30.10.2016. 1 +. S3 Mora-

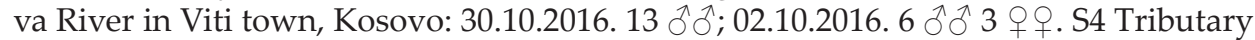

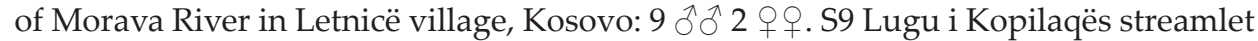

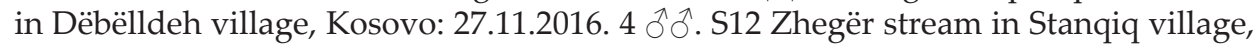
Kosovo: 09.10.2016. 1 ô.

Rhyacophila nubila Zetterstedt, 1840

S11 Morava River in Korbliq village, Kosovo: 30.10.2016. 2 ふ઼

\section{Family Philopotamidae}

Philopotamus montanus (Donovan, 1813)

S5 Tributary of Vardar River in Brodec Village, Macedonia: 25.09.2016. 5 ठぇ 1 q. S13 Stream in Dërmjak village, Kosovo: 02.10.2016. 2 ๙ึ. S15 Streamlet before Tanushë village, Macedonia: 25.09.2016. 1 ふ઼.

Wormaldia occipitalis (Pictet, 1834)

S12 Zhegër stream in Stanqiq village, Kosovo: 09.10.2016. 1 §. S15 Streamlet before Tanushë village, Macedonia: 25.09.2016. 1 ऽ. S14 Stream above Brodec village, Macedonia: 25.09.2016. 4 ถึฎ 2 우.

\section{Family Limnephilidae}

Micropterna nycterobia McLachlan, 1875

S1 Tributary of Morava River in Binçë village, Kosovo: 27.11.2016. 2 $ぇ$ đ. S7 River in

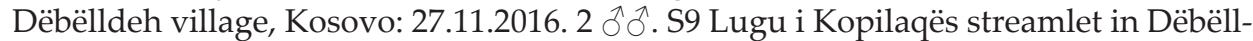
deh village, Kosovo: 27.11.2016. 1 .

Micropterna sp.

S1 Tributary of Morava River in Binçë village, Kosovo: 27.11.2016. 1 ภ Limnephilus lunatus Curtis, 1834

S2 Tributary of Morava River in Shushtë village, Kosovo: 30.10.2016. 1 q. S4 Tributary of Morava River in Letnicë village, Kosovo: 04.11.2016. 1 q.

Stenophylax meridiorientalis Malicky, 1982

S1 Tributary of Morava River in Binçë village, Kosovo: 27.11.2016. 1 đ̊. 
Halesus digitatus (Schrank, 1781)

S1 Tributary of Morava River in Binçë village, Kosovo: 27.11.2016. 1 đ. S3 Morava River in Viti town, Kosovo: 30.10.2016. 1 ऽ. S6 Tributary of Zhegër stream in Zhegër village, Kosovo: 30.10.2016. 3 ふึ. S8 Llapushnicë River in Pogragjë village, Kosovo: 27.11.2016. 1 đ. S11 Morava River in Korbliq village, Kosovo: 30.10.2016. 1 §.

Potamophylax pallidus (Klapálek, 1899)

S5 Tributary of Vardar River in Brodec Village, Macedonia: 25.09.2016. 2 q.

Drusus botosaneanui Kumanski, 1968

S10 Streamlet before Brodec village, Macedonia: 25.09.2016. 1 ठ̊.

Chaetopteroides sp.

S15 Streamlet before Tanushë village, Macedonia: 21.09.2016 1 q; 25.09.2016 2 q .

S9 Lugu i Kopilaqës streamlet in Dëbëlldeh village, Kosovo: 27.11.2016. $1 \delta$.

Chaetopteryx bosniaca Marinkovic-Gospodnetic, 1959

S9 Lugu i Kopilaqës streamlet in Dëbëlldeh village, Kosovo: 27.11.2016. 1 § 1 q.

Chaetopteryx gonospina Marinkovic-Gospodnetic, 1966

S7 River in Dëbëlldeh village, Kosovo: 27.11.2016. 1 đ.

\section{Family Uenoidae}

Thremma anomalum McLachlan, 1876

S14 Stream above Brodec village, Macedonia: 25.09.2016. 3 ðð.

\section{Family Leptoceridae}

Mystacides azurea (Linnaeus, 1761)

S16 Stream in Tabanovc village, Macedonia: 21.09.2016. 1 đ.

\section{DISCUSSION}

During this investigation we found two species which are quite rare in the Balkan Peninsula: Chaetopteryx gonospina and Rhyacophila fischeri.

Chaetopteryx gonospina was described from Bosnia and Herzegovina and is reported for the first time from Kosovo. It was found at Station S7 in Dëbëlldeh village close to the border with Macedonia. This species has a disjunct distribution and is currently known only from Ecoregions 2 and 5 according to Illies (ILLiEs, 1978), i.e. from the Iberian Peninsula, Croatia, Bosnia and Herzegovina and recently Montenegro (GoNzÁlez \& Martínez, 2011; Kučinić et al., 2013; MalícKy, 2017; OláH \& Kovács, 2012). Our finding in Kosovo is the first record for Ecoregion 6. Like other species of the genus Chaetopteryx Stephens, 1837, this species is also associated with the upper courses of small streams. Chaetopteryx gonospina was previously found at different altitudes, from $500 \mathrm{~m}$ a.s.l. up to the alpine area. During our investigation it was found at $982 \mathrm{~m}$ a.s.l. Very close to the locality where C. gonospina was found, we sampled another species of the genus Chaetopteryx, Chaetopteryx bosniaca. This species is also rare in Kosovo and is known from 5 localities at different altitudes (IвRAнiм et al., 2012a, 2014a, 2015a, b). This is the first time that two species of the genus Chaetopteryx are recorded at such 
close proximity in Kosovo. One male and one female specimen belonging to the genus Chaetopteroides were also collected in the same area but at the Macedonian side of the Karadak Mts. Species of these two genera prefer spring areas or the upper reaches of small to medium streams, without pollution, which are well shaded by riparian and nearby vegetation.

Rhyacophila fischeri was originally described from Romania and is currently known from Ecoregions 5, 7 and 10 (Graf et al., 2008). During this investigation we report it for the first time from Ecoregion 6; it is also the first record for the Republic of Macedonia based on reliable adult specimens. Although reported from Fauna Europaea as present in Macedonia, we could not trace any record in published literature about caddisflies of Macedonia based on adult specimens. This species is reported from a variety of altitudes, from $500 \mathrm{~m}$ up to $1900 \mathrm{~m}$ a.s.l. and is mainly associated with upper reaches of mountainous streams (GRAF et al., 2008). During our investigation we found it in three localities: S5, S14 and S15 in altitudes from $950 \mathrm{~m}$ up to $1358 \mathrm{~m}$ a.s.1.. All localities are situated in beech forests. In Kosovo more than 10 localities of this species are currently known (IвRAнiмi et al., 2012b).

This investigation contributes to the knowledge on the faunistics and distribution of several other rare, endangered and endemic species such as: Chaetopteryx bosniaca, Drusus botosaneanui, Rhyacophila nubila, R. obliterata, and Stenophylax meridiorientalis. Based on our preliminary results, the Karadak Mts. are home to an interesting caddisfly community. This investigation adds to the distributional patterns and ecological information regarding caddisflies of a rarely studied area in the Balkans, namely Kosovo and Macedonia (e.g. Iвrahim et al., 2012a, b, 2014a, b; Rimcheska et al., 2015; Slavevska-Stamenković et al., 2016).

\section{ACKNOWLEDGEMENT}

We would like to thank two reviewers, Wolfram Graf and Ana Previšić, whose comments significantly improved this manuscript.

Received October 30, 2017

\section{REFERENCES}

Gashi, A., Ibrahimi, H., Grapci-Kotori, L., Sejdiu, N. \& Bislimi, K., 2015: New Records of Drusus siveci Malicky, 1981 (Trichoptera, Limnephilidae, Drusinae) from the Balkan Peninsula, with Ecological Notes. Acta Zoologica Bulgarica 67 (2), 259-264.

González, M. \& Martínez, J., 2011: Checklist of the caddisfies of the Iberian Peninsula and Balearic Islands (Trichoptera). Zoosymposia 5, 115 - 135.

Graf, W., Murphy, J., Dahl, J., Zamora-Muñoz C. \& López-Rodríguez, J. M., 2008: Trichoptera. In: Distribution and Ecological Preferences of European Freshwater Organisms. Series Ed. Schmidt-Kloiber, A. \& Hering, D. 1, 1-388.

Ibrahimi, H., Kučinić, M., Vitecek, S., Waringer, J., Graf, W., Previšić, A., Bálínt, M. \& Keresztes, L., PAuls, S.U., 2015a: New records for the Kosovo caddisfly fauna with the description of a new species, Drusus dardanicus sp. nov. (Trichoptera: Limnephilidae). Zootaxa 4032, 551-568. DOI:10.11646/zootaxa.4032.5.5

Iвrahimi, H., Gashí, A., Grapci-Kotorí, L., Zhushí-Etemí, F., Bílalli, A. \& Musliu, M., 2015b: New Distribution and Species Records of Caddisflies (Insecta: Trichoptera) from the Republic of Kosovo. Entomological News 125 (4), 229-238. 
Ibrahimi, H., Gashi, A., Bilalli, A., Musliu, M., Grapci Kotori, L. \& Etemi-Zhushi, F., 2014a: Three new country records from the genus Limnephilus Leach, 1815 (Trichoptera: Limnephilidae) from the Republic of Kosovo. Biodiversity Data Journal 2, e4140. doi: 10.3897/BDJ.2.e4140

Ibrahimi, H., Kučinić, M., Gashi, A. \& Grapci-Kotori, L., 2014b: Trichoptera Biodiversity of the Aegean and Adriatic Sea basins in Kosovo. Journal of Insect Science 14 (209), 1-8. doi: 10.1093/jisesa/ieu071

Ibrahimi, H., Gashi, A., Grapci-Kotori, L. \& Kučinić, M., 2013: First records of the genus Micropterna Stein, 1873 (Insecta: Trichoptera) in Kosovo with distributional and ecological notes. Natura Croatica 22 (1), 147-155.

Ibrahimi, H., Kučinić, M., Gashi, A. \& Grapci-Kotori, L., 2012a: The caddisfly fauna (Insecta, Trichoptera) of the rivers of the Black Sea basin in Kosovo with distributional data for some rare species. ZooKeys 182, 71-85. doi: 10.3897/zookeys.182.2485.

Ibrahimi, H., Kučinić, M., Gashi, A., Grapci-Kotori, L., VučKović, I. \& Cerjanec, D., 2012b: The genus Rhyacophila Pictet, 1873 (Insecta: Trichoptera) in Kosovo. Aquatic Insects: International Journal of Freshwater Entomology 34 (1), 23-31. doi: 10.1080/01650424.2012.643021.

Ibrahimi, H., Previšić, A., Vitecek, S., Graf, W., Kučinić, M., Bálint, M., Keresztes, L. \& Pauls, S.U., 2016: Drusus sharrensis sp.n. (Trichoptera, Limnerphilidae) a new species from Sharr National Park in Kosovo with molecular and ecological notes. ZooKeys 559, 107-124. doi: 10.3897/zookeys.559.6350.

Illies, J. (ed.), 1978: Limnofauna Europaea. A Checklist of the Animals Inhabiting European Inland Waters, with an Account of their Distribution and Ecology. 2nd Edition. Gustav Fischer Verlag, Stuttgart. 552pp.

Kučinić, M, Szivák, I., PAuls, S.U., BÁLint, M., Delić, A. \& VučKović, I., 2013: Chaetopteryx bucari sp. n., a new species from the Chaetopteryx rugulosa group from Croatia (Insecta, Trichoptera, Limnephilidae) with molecular, taxonomic and ecological notes on the group. Zookeys 320, 1-28. doi: 10.3897/zookeys.320.4565

Kumanski, K., 1985: Trichoptera, Annulipalpia. Fauna Bulgarica 15. Bulgarska Akademi na Naukite, Sofia. 243 pp.

Malicky, H., 2004: Atlas of European Trichoptera. 2nd Edition. Springer, Netherlands. 359 pp.

Malicky, H., 2005: Die Köcherfliegen Griechenlands. Denisia 17, 1-240.

Malicky, H., 2017: Fauna Europaea: Trichoptera. Fauna Europaea version 2017.06, https://fauna-eu.org

Morse, J.C., 2017: Trichoptera World Checklist. http://entweb.clemson.edu/database/trichopt/, accessed September 27, 2017.

OláH, J., \& Kovács, T., 2012. New records of Chaetopterygini species (Trichoptera: Limnephilidae). Folia Historico Naturalia Musei Matraensis 36, 81-88.

OlÁH, J., \& KovÁcs, T., 2013: New species and records of Balkan Trichoptera II. Folia Historico Naturalia Musei Matraensis 37, 109-121.

OlÁH, J., \& KovÁcs, T., 2014: New species and records of Balkan Trichoptera III. Folia Historico Naturalia Musei Matraensis 38, 97-131.

OlÁH, J., 2010: New species and new records of Palearctic Trichoptera in the material of the Hungarian Natural History Museum. Annales Historico-Naturales Musei Nationalis Hungarici 102, 65-117.

OцÁH, J., 2011: New species and records of Balkan Trichoptera. Folia Historico Naturalia Musei Matraensis 35, 111-121.

Oláh, J., Iвrahimi, H. \& Kovács, T., 2013a: The genus Chaetopteroides (Trichoptera, Limnephilidae) revised by fine structure analysis of parameres. Folia Historico Naturalia Musei Matraensis 37, 93-108.

Oláh, J., Andersen, T., Chvojka, P., Coppa, G., Graf, W., Ibrahimi, H., Previšić, A. \& Valle, M., 2013b: The Potamophylax nigricornis group (Trichoptera, Limnephilidae): resolution of phylogenetic species by fine structure analysis. Opuscula Zoologica Budapest 44 (2), 167-200.

Oláh, J., Kovács, T., Sivec, I., Szivák, I. \& Urbanic, G., 2012: Seven new species in the Chaetopteryx rugulosa species group: applying the phylogenetic species concept and the sexual selection theory (Trichoptera, Limnephilidae). Folia Historico Naturalia Musei Matraensis 36, 51-79.

Previšić, A., Schnitzler, J., Kučinić, M., Graf, W., Ibrahimi, H., Kerovec, M. \& Pauls, S.U., 2014: Micro-scale vicariance and diversification of Western Balkan Caddisflies linked to Karstification. Freshwater science 33, 250-262.

Rimcheska, B., Slavevska-Stamenković V., Ibrahimi H., Smíjjov S., Rístovska, M. \& Paunović, M., 2015 : First Record of the Genus Helicopsyche von Siebold, 1856 (Trichoptera: Helicopsychidae) from the Republic of Macedonia. Acta Zoologica Bulgarica 67 (3), 443-446. 
Schmidt-Kloiber, A., Neu, P. J., Malicky, M., Pletterbauer, F., Malicky, H. \& Graf, W., 2017: Aquatic biodiversity in Europe: a unique dataset on the distribution of Trichoptera species with important implications for conservation. Hydrobiologia 797 (1), 11-27. doi: 10.1007/s10750-017-3116-4

Slavevska-Stamenković, V., Rimcheska, B., Vidinova, Y., Tyufekchieva V., Ristovska, M., Smiljkov, S., Paunović, M. \& Prelić, D., 2016: New Data on Ephemeroptera, Plecoptera and Trichoptera from the Republic of Macedonia. Acta Zoologica Bulgarica 68 (2), 199-206.

Vitecek, S., Kučinić, M., Oláh, J., Previšić, A., Bálint, M., Keresztes, L., Waringer, J., Pauls, S. U. \& Graf, W., 2015: Description of two new filtering carnivore Drusus species (Limnephilidae, Drusinae) from the Western Balkans. ZooKeys 513, 79-104. doi: 10.3897/zookeys.513.9908

Vučković, I., Previšić, A., Graf, W. \& Kučınić, M., 2011: Description of the female and new data on the distribution of Annitella apfelbecki Klapálek, 1899 (Insecta: Trichoptera). Aquatic insects 33, 381-389.

Waringer, J., Graf, W., Kučinić, M., Previšić, A. \& VučKović, I., 2009: The larva and life cycle of Annitella apfelbecki Klapalek, 1899, including a re-description of Melampophylax nepos McLachlan, 1880 (Trichoptera: Limnephilidae). Aquatic insects 31 (1), 71-80.

Wiberg-Larsen, P., 2008: Overall distributional patterns of European Trichoptera. Ferrantia 55, $143-155$.

Žıvić, I., Marković, Z. \& Brajković, M., 2006: Contribution to the faunistical list of Trichoptera (Insecta) of Serbia. Acta Entomologica Slovenica 14, 55-88.

\title{
SUMMARY
}

\section{First records of the caddisfly fauna (Insecta: Trichoptera) from the Kara- dak Mountains, Western Balkans}

\author{
A. Bilalli, H. Ibrahimi \& M. Musliu
}

In this study we present the first data about the caddisflies of the Karadak Mountains (Kosovo and Macedonia). Caddisfly specimens were collected from September 2016 to June 2017 at sixteen localities. In total, 18 species belonging to five families were found. During this investigation we found two new records for the caddisfly fauna, one for Kosovo and one for Macedonia. Chaetopteryx gonospina is recorded for the first time from Kosovo and Rhyacophila fischeri is recorded for the first time from Macedonia. Several other species found during this investigation are rare, with a limited distribution in the Balkan Peninsula.

This investigation contributes to the knowledge on the distribution of caddisflies in Kosovo and Macedonia and highlights the Karadak Mountains as an important hotspot of caddisfly diversity, which was almost completely unknown until now. 
